\title{
Kadar radikal superoksid (O2-), nitric oxide (NO) dan asupan lemak pada pasien hipertensi dan tidak hipertensi
}

\author{
Pudji Astutik $^{1}$, Merryana Adriani ${ }^{2}$, Bambang Wirjatmadi
}

\begin{abstract}
Background : Hypertension closely related to impaired endothelial dependent vasodilation due to a decline in the availability of nitric oksid (NO) and high fat intake, decreased Nitric Oksid caused due to increased levels of superoksid.

Objective: to analyze the differences in the levels of Superoksid Radical (O2-), Nitric oxide (NO) and fat intake in patients with hypertension and not hypertension .

Methods : this research is cross sectional, research amount sampelnya taken at random. 24 respondent patients consisting of 12 cases control, and 12 the age of 65 40-tahun.pengambilan samples conducted in outpatient installation regional general hospital Sidoarjo. Done bseline superoksid levels, nitric oxide and recall fat intake.

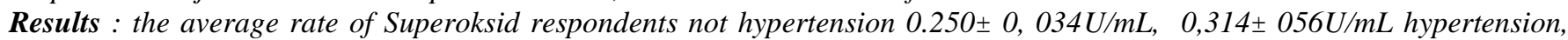

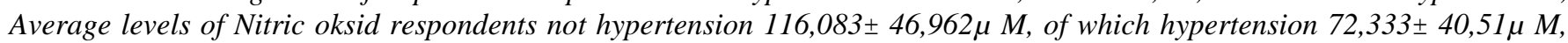

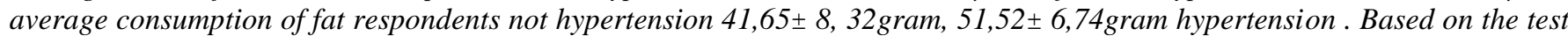
results the difference against Superoksid levels of both research groups using a t-test two samples are free retrieved the value $p<0,05(p=0,004)$, NO content retrieved the value $p<0,05(p=0,023)$, fat intake obtained the value of $p<0,05(p=$ $0,004)$ which means that there is a meaningful difference in the levels of Superoksid, Nitric oxide and the level of fat intake among respondents with no hypertension and hypertension.

Conclusion : there is a radical difference in the levels of Superoksid, NO (Nitric Oxide) and fat intake in patients with hypertension and not hypertension.
\end{abstract}

Key words : hypertension, radical superoksid, nitric oxide, fat consumption

\begin{abstract}
ABSTRAK
Latar Belakang : Hipertensi erat kaitannya dengan gangguan vasodilatasi yang terjadi karena menurunnya kadar Nitrit Oksida (NO) dan asupan tinggi lemak. Penurunan NO disebabkan karena meningkatnya kadar superoksida.

Tujuan : Tujuan dari penelitian ini adalah menganalisis perbedaan kadar superoksida, nitrit oksida, dan asupan lemak pada pasien dengan hipertensi dan tidak hipertensi.

Metoda : Studi cross sectional pada 24 pasien di Instalasi Rawat Jalan Rumah Sakit Umum Daerah Kabupaten Sidoarjo, berumur 40-65 tahun, dipilih secara acak, yang terbagi dalam dua kelompok, 12 pasien tidak hipertensi dan 12 pasien dengan hipertensi. Data yang dikumpulkan adalah kadar superoksida, nitrit oksida dan asupan lemak.

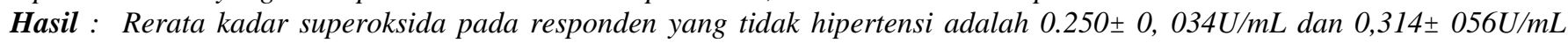

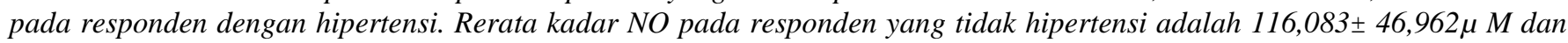
$72,333 \pm 40,51 \mu$ M pada responden dengan hipertensi. Rerata asupan lemak pada responden yang tidak hipertensi adalah

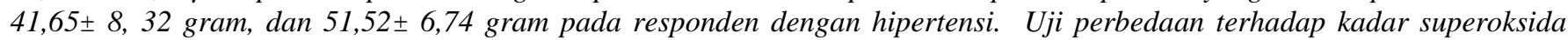
kedua kelompok dengan menggunakan uji t dua sampel bebas diperoleh nilai $p<0,05(p=0,004), N O(p=0,023)$, dan asupan lemak $(p=0,004)$ yang menunjukkan terdapat perbedaan yang bermakna pada kadar superoksida, NO, asupan lemak antara kelompok responden dengan tidak hipertensi dan hipertensi.

Simpulan : Ada perbedaan kadar superoksida, nitrit oksida, dan asupan lemak pada pasien dengan hipertensi dan tidak hipertensi.
\end{abstract}

Kata kunci : hipertensi, kadar superoksida, nitrit oksida, asupan lemak

\section{PENDAHULUAN}

Pada tahun 2020 diperkirakan kasus penyakit tidak menular akan meningkat menjadi $73 \%$ sebagai penyebab kematian, dan merupakan $60 \%$ beban penyakit dunia. WHO SEARO (South East Regional Office) termasuk Indonesia, Thailand, Myanmar serta

\footnotetext{
${ }^{1}$ Magister Fakultas Kesehatan Masyarakat Universitas Airlangga, Indonesia

${ }^{2}$ Fakultas Kesehatan Masyarakat Universitas Airlangga, Indonesia
}

berbagai negara Asia selatan, melaporkan bahwa 52\% penyebab kematian di tahun 2000 adalah penyakit tidak menular, 9\% akibat kecelakaan dan 39\% akibat penyakit menular serta penyakit lainnya. ${ }^{1}$ Salah satu penyakit tidak menular tersebut adalah hipertensi.

Berdasarkan data The National Health and Examination Survey NHANES ) menunjukkan bahwa dari tahun 1999 - 2000, insiden hypertensi pada orang dewasa adalah sekitar $29-31 \%$, yang berarti terdapat 58-65 juta penderita hypertensi di Amerika, dan 
terjadi peningkatan 15 juta dari data NHANES) pada tahun 1988-1991. ${ }^{2}$

Prevalensi hipertensi di Indonesia berdasarkan hasil Survei Kesehatan Rumah Tangga tahun 2004 sebesar 21\% (Litbang-Kes. 2005) dan meningkat menjadi 32,2\% pada tahun 2007,.(Depkes 2007).

Penyakit Hipertensi merupakan masalah yang besar dan serius. Disamping karena prevalensinya yang tinggi dan cenderung meningkat di masa yang akan datang, juga karena tingkat keganasan penyakit yang diakibatkan sangat tinggi seperti penyakit jantung, stroke,gagal ginjal dan lain lain, juga menimbulkan kecacatan permanen dan kematian mendadak. Kehadiran hipertensi pada kelompok dewasa muda, sangat membebani perekonomian keluarga, karena biaya pengobatan yang mahal dan membutuhkan waktu yang panjang, bahkan seumur hidup. ${ }^{3}$

Beberapa penelitian menunjukkan bahwa gangguan vasodilatasi yang tergantung endotel terjadi pada penderita hipertensi, karena fungsi endotel berhubungan dengan bioaktivitas dari NO yang tergantung interaksinya dengan ROS khususnya superoxid. Reaksi NO dengan superoxid akan dihasilkan peroxynitrit (ONOO-) yang merupakan reaktif nitrogen spesies. Peroksinitrit ini akan mengoksidasi BH4 (pteridin tetrahydrobiopterin) yang merupakan kofaktor untuk NOS (Nitric oxide syntthase). Situasi ini akan mengakibatkan NOS untuk menghasilkan superoksida daripada menghasilkan NO, sebagai akibatnya sintesis NO menurun. Penurunan kadar NO menyebabkan proses relaksasi endotel terganggu sehingga berakibat terjadinya hipertensi. ${ }^{4}$

Peningkatan produksi superoxid dapat meningkatkan degradasi NO untuk menurunkan sintesisNO. Degradasi NO akan menyebabkan disfungsi vasomotor, aktivasi endotel mengekpresikan molekul adhesi, proliferasi otot polos menginduksi, ekspresi gen inflamasi, menginduksi apoptosis, migrasi dan reorganisasi matrik seluler yang dapat mengganggu vasorelaksasi yang tergantung endotel , semuanya ini merupakan mekanisme yang mengawali terjadinya hipertensi. ${ }^{5}$

Nitric Oxide yang juga dikenal sebagai nitrogen monoksida, merupakan zat perantara yang sangat penting dalam siklus kimia di dalam tubuh. Pada manusia,senyawa NitricOxide merupakan senyawa kimia yang penting untuk tranportasi sinyal listrik didalam sel-sel, dan berfungsi dalam proses fisiologis dan patologis. Demikian pula, senyawa ini bisa menyebabkan pelebaran pembuluh darah atau dalam istilah kedokteran di sebut vasodilator yang kuat sehingga bisa menurunkan tekanan darah. ${ }^{6}$

Nitric Oxide (NO) berperan terhadap regulasi dan pemeliharaan tekanan pembuluh darah. NO dihasilkan sel endotel, dan memiliki efek vasodilatasi dan antiproliferasi pada sel otot polos vaskular. Pelepasan NO akan memicu terjadinya relaksasi otot polos vaskular. Penurunan NO dapat terjadi akibat adanya penurunan aktivitas enzim Nitric Oxide Synthase (NOS). Penurunan aktivitas NOS menyebabkan vasokonstriksi dan hipertensi. $^{7}$

Makanan tinggi lemak tidak memberi rasa kenyang, hanya memberikan rasa gurih sehingga menyebabkan volume makanan lebih besar supaya kenyang.Besarnya volume makanan dengan kandungan lemak tinggi, memberikan energi lebih tinggi, sehingga menjadi kendala dalam mengatur keseimbangan energi.Kecenderungan perilaku makan yang tinggi lemak akan menjadi ketidakseimbangan lemak yang akan disimpan dalam jaringan adiposa, mengakibatkan adanya penimbunan jaringan lemak di dalam tubuh. ${ }^{8}$ Selain sebagai tempat penyimpanan energi, jaringan lemak juga menghasilkan faktor yang menyebabkan hipertensi karena jaringan lemak dapat menguraikan angiotensin dari sistem angiotensinrenin. ${ }^{9}$

Asupan Lemak yang berlebihan akan menginduksi aktifasi sel endotel vaskuler, yang pada gilirannya dapat mengakibatkan disfungsi endotel dan produksi Reactive Oxygen Species (ROS), penurunan produksi Nitrit Oksida (NO), dan oksidasi LDL melalui peningkatan substrat, perubahan konformasi LDL yang lebih rentan terhadap oksidasi, dan peningkatan produksi radikal superoksida (O2-) vaskuler. ${ }^{10}$

Lemak yang memiliki Apo-B 100 (VLDL, IDL, LDL) bila terdapat dalam jumlah banyak dan dalam waktu yang lama dapat menimbulkan deposisikolesterol dan ester kolesteril pada jaringan ikat dinding pembuluh arteri. Jaringan otot halus dan jaringan fibrosa di sekitarnya akan berproliferasi membentuk plak. Dengan berjalannya waktu, plak akan bertambah besar. Plak yang bertambah besar ditambah dengan garam kalsium yang ikut mengendap akan menyebabkan aterosklerosis. ${ }^{11}$ Telah diketahui bahwa aterosklerosis merupakan salah satu penyebab terjadinya hipertensi.

Penelitian ini bertujuan untuk mengetahui perbedaan kadar Superoxide, Nitric Oxide (NO) dan tingkat konsumsi Lemak pada pasien Hipertensi dan tidak Hipertensi.

\section{METODE DAN BAHAN}

Rancangan penelitian ini adalah cross sectional, terhadap 24 pasien di Instalasi Rawat Jalan Rumah Sakit Umum Daerah Kabupaten Sidoarjo, dipilih secara acak,yang terbagi dalam dua kelompok, 12 pasien tidak hipertensi dan 12 pasien dengan hipertensi.Kriteria inklusi penlitian ini adalah pasien 
yang berobat di Instalasi Rawat Jalan di RSUD Sidoarjo, berumur 40-65tahun, yang telah diperiksa tekanan darahnya, kemudian dibagi menjadi dua kelompok yaitu kelompok tidak hipertensi dan hipertensi (hipertensi primer, hipertensi sistolik, hipertensi diastolik, hipertensi campuran). Pasien tidak mempunyai komplikasi penyakit lain seperti diabetes mellitus, gangguan ginjal, gangguan jantung juga tidak mengalami stroke, serta bersedia berpartisipasi dalam penelitian ini dan bersedia diukur kadar superoxide, NO-nya, dengan menandatangani informed consent.

Definisi hipertensi dalam penelitian ini berdasarkan The Seventh Report of the Joint National Commitee on Prevention of Hight Blood Pressure (JNC VII). Seseorang dikatakan Hipertensi apabila tekanan darah diastolik $\geq 90 \mathrm{mmHg}$ dan atau sistolik $\geq 140 \mathrm{mmHg}$. Subyek kontrol adalah pasien dengan kriteria sama dengan subyek kasus tetapi tidak hipertensi.Penelitian ini juga sudah disetujui Komite Etik Fakultas Kesehatan Masyarakat Universitas Airlangga Surabaya. Jumlah Responden disesuaikan dengan rumus. ${ }^{12}$ Pengambilan bahan pemeriksaan darah diambil dari vena cubiti sampel sebanyak $5 \mathrm{ml}$ ditempatkan pada vacutainer dengan antikoagulan EDTA, pengukuran kadar superoxide menggunakan Superoxide Dismutase Assay kitCat 706002. Tahap akhir dilakukan pembacaan hasil Optical Density (OD) superoksida menggunakan ELISA reader dengan panjang gelombang $450 \mathrm{~nm}$. Pemeriksaan kadar NO diukur secara Calorimetrik Non-enzymatic Nitric Oxide Assay dan menggunakan kit dari $R \& D$ Biomedical Research product dengan prinsip kerja yaitu mengukur kadar nitrit yang merupakan hasil degradasi nitrik oksida (NO) yang bersifat stabil secara spektrofotometri pada panjang gelombang $540 \mathrm{~nm}$. Nitrat yang juga merupakan hasil degradasi NO akan dirubah terlebih dahulu menjadi nitrit dengan bantuan logam kadmium (Cd).Sedangkan konsumsi lemak diperoleh dari recall 1x24 jam, kemudian dikonversi ke gram dengan menggunakan DKBM, selanjutnya dibandingkan dengan AKG.

Analisa secara statistik univariat digunakan untuk menghitung nilai rerata (mean) dan standart deviasi (SD) dari kadar superoxide, NO dan tingkat asupan lemak pada setiap kelompok. Uji beda dilakukan menggunakan uji t dengan $\mathrm{p}<0,05$ untuk mencari ada tidaknya perbedaan antara kadar superoxide, NO dan tingkat konsumsi lemak pada pasien hipertensi dan tidak hipertensi.

\section{HASIL}

Karakteristik demografi responden pasien bisa dilihat pada tabel 1. Usia rerata responden tidak hipertensi $46,083 \pm 4,420$,responden hipertensi $52,583 \pm 4,852$. Responden wanita lebih banyak dibandingkan pria baik pada responden tidak hipertensi (75\%) maupun responden hipertensi $(66,7 \%)$. Riwayat penyakit keluarga hipertensi terbanyak adalah dari ibunya pada responden tidak hipertensi (33,3\%)maupun hipertensi (41,7\%).

Pada tabel 2 bisa dilihat rerata kadar superoxide responden tidak hipertensi $0,250 \pm 0,034 \mathrm{U} / \mathrm{mL}$, responden yang hipertensi $0,314 \pm 0,056 \mathrm{U} / \mathrm{mL}$. rerata kadar NO responden tidak hipertensi 116,083 \pm $46,962 \mu \mathrm{M}$, responden yang hipertensi $72,333 \pm 40,511 \mu \mathrm{M}$. Untuk rerata konsumsi lemak responden tidak hipertensi 41,65 $\pm 8,32$ gram, responden yang hipertensi 51,52 $\pm 6,74$ gram. Berdasarkan hasil Uji perbedaan terhadap kadar superoxidekedua kelompok penelitian dengan menggunakan uji t dua sampel bebas diperoleh nilai $\mathrm{p}$ $<0,05(\mathrm{p}=0,004), \mathrm{NO}(\mathrm{p}=0,023)$, dan asupan lemak $(\mathrm{p}=\quad 0,004) \quad$ yang menunjukkan

Tabel 1. Karakteristik demografi responden tidak hipertensi dan hipertensi

\begin{tabular}{lcc}
\hline \multicolumn{1}{c}{ Variabel } & $\begin{array}{c}\text { Kontrol } \\
(\mathrm{n}=12)\end{array}$ & $\begin{array}{c}\text { Kasus } \\
(\mathrm{n}=12)\end{array}$ \\
\hline Umur & $46,0 \pm 4,42$ & $52,5 \pm 4,85$ \\
Jenis Kelamin & & \\
$\quad$ Laki -laki & 3 & 4 \\
$\quad$ Perempuan & 9 & 8 \\
Riwayat penyakit keluarga & & \\
$\quad$ Tidak ada & 5 & 2 \\
Ada (ibu) & 4 & 5 \\
Ada (ayah) & 2 & 1 \\
Ada (ayah,ibu) & 1 & 3 \\
Tidak Tahu & 0 & 1 \\
\hline
\end{tabular}


Tabel 2. Kadar Superoxide, Nitric Oxide dan asupan lemak pada responden tidak hipertensi dan hipertensi

\begin{tabular}{lllllll}
\hline \multirow{2}{*}{ Variabel } & \multicolumn{3}{c}{ Tidak Hipertensi } & \multicolumn{3}{c}{ Hipertensi } \\
\cline { 2 - 7 } & \multicolumn{1}{c}{ Kadar } & Kadar Nitric & Asupan & Kadar & Kadar Nitric & Asupan \\
Oxide & Lemak \\
\hline Mean & 0,250 & 116,083 & 41,65 & 0,314 & 72,333 & 51,52 \\
Std. Deviasi & 0,034 & 46,962 & 8,32 & 0,056 & 40,511 & 6,74 \\
Nilai Minimum & 0,214 & 71 & 27,65 & 0.239 & 24,333 & 43,2 \\
Nilai Maximum & 0,322 & 205,666 & 54,55 & 0,394 & 351,666 & 61,85 \\
\hline
\end{tabular}

terdapat perbedaan yang bermakna pada kadar superoxide, NO, asupan lemak antara kelompok responden dengan tidak hipertensi dan hipertensi, seperti terlihat pada gambar $1-3$.

\section{PEMBAHASAN}

Berdasarkan data hasil penelitian nilai OD (Optical Density) kadar Superoksida didapatkan hasil analisis statistik $\mathrm{p}<0,05(\mathrm{p}=0,004)$ yang menunjukkan ada perbedaan yang bermakna kadar Superoksida pada kelompok responden tidak hipertensi dan hipertensi, tidak hipertensi reratanya sebesar $0,250 \pm 0,034 \mathrm{U} / \mathrm{mL}$, sedangkan hipertensi adalah sebesar 0,314 $\pm 0,056$ U/mL. Hasil penelitian ini bisa dijelaskan bahwa adanya perbedaan pada responden tidak hipertensi dan hipertensi yang ditunjukkan dengan hasil nilai $\mathrm{OD}($ Optical

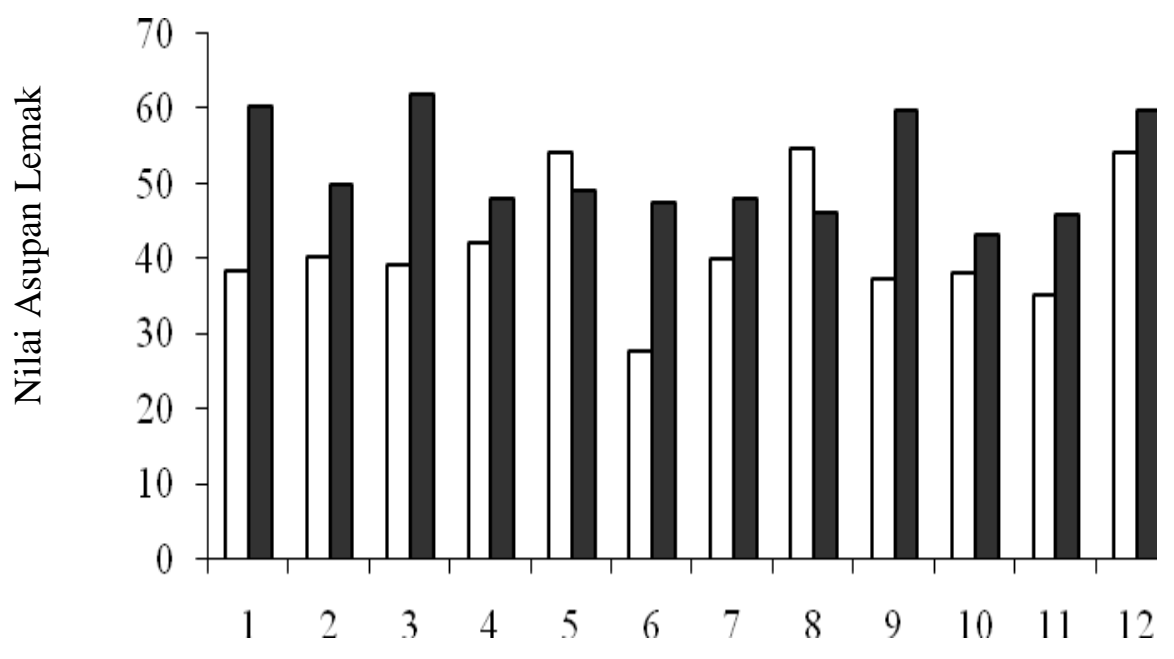

Gambar 1. Gambaran asupan Lemak pada Responden

Ket $: \square=$ Tidak Hipertensi, $\square=$ Hipertensi

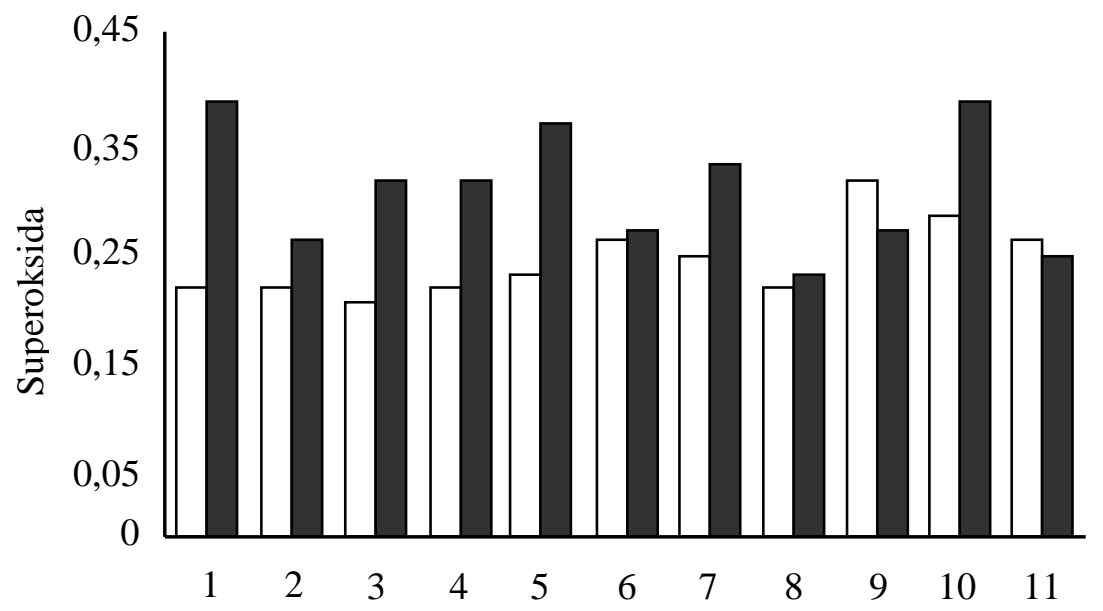

Gambar 2. Gambaran Kadar Superoxide pada responden Ket $: \square=$ Tidak Hipertensi, $\square=$ Hipertensi 


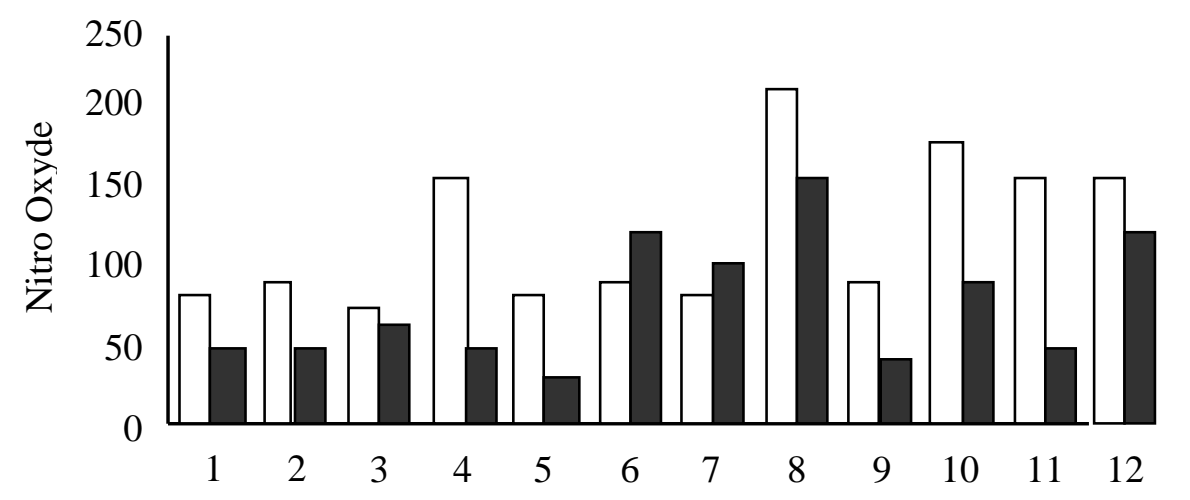

Gambar 3. Gambaran Kadar Nitric Oxide pada responden Ket : $\square=$ Tidak Hipertensi, $\square=$ Hipertensi

Density) superoksida-nya, hal ini dimungkinkan karena pengaruh stress, baik yang disebabkan oleh stress fisik yang berlebihan atau stres emosional, karena dalam penelitian ini menunjukkan ada hubungan antara stres dan terjadinya hipertensi, juga karena dipengaruhi kadar lipida darah responden. Stress dapat menyebabkan sympatoadrenal discharge, yang ditunjukkan dengan peningkatan kadar nonadrenalin dan adrenalin yang sangat tinggi. ${ }^{13}$ Hasil penelitian Sozmen et al juga menjekaskan katekholamine (noradrenalin dan adrenalin) sebagai sumber yang sangat penting dalam pembentukan radikal bebas oksigen yaitu dengan cara autooksidasi dalam reaksi yang sangat komplek. ${ }^{14}$ Stres juga diketahui akan dapat mengurangi efektifitas pemanfaatan antioksidan didalam tubuh sehingga menyebabkan ketidakseimbangan antara pembentu-kan radikal bebas dengan sistem scavenger akan timbul suatu keadaan yang disebut stres oksidatif dan hal ini dapat menyebabkan kerusakan sel yang berakibat terjadinya penyakit, antara lain hipertensi. ${ }^{.5}$

Hasil analisis statistik pada penelitian ini didapatkan $\mathrm{p}<0,05(\mathrm{p}=0,023)$ berarti ada perbedaan yang bermakna kadar NO pada responden dengan tidak hipertensi dan hipertensi. artinya rata-rata kadar NO dengan standar deviasi pada responden dengan tidak hipertensi sebesar 116,083 $\pm 46,962 \mu \mathrm{mol} / \mathrm{L}$, sedangkan rata-rata dan standar deviasi responden dengan hipertensi sebesar 72,333 $\pm 40,511 \mu \mathrm{mol} / \mathrm{L}$.

Hal ini sejalan dengan penelitian Santosa menyatakan bahwa ada perbedaan kadar NO pada pasien hipertensi dan tidak hipertensi. ${ }^{4}$ Sesuai dengan teori yang menyebutkan bahwa semakin rendah kadar nitrik oksida (NO) darah, semakin tinggi pula tekanan darah sistolik dan diastolik, karena NO merupakan senyawa yang bersifat vasodilator. ${ }^{16}$ Semakin parah kerusakan endotel akibat stres oksidatif yang berlebihan, maka produksi NO akan semakin rendah, tekanan darah meninggi dan hipertensi bertambah berat. ${ }^{17} \mathrm{Hal}$ ini juga sesuai dengan pendapat Taddei yang mengemukakan gangguan vasodilatasi yang bergantung endotel pada penderita hipertensi dikarenakan penurunan ketersediaan NO. ${ }^{18}$

Rerata tingkat konsumsi lemak dan standar deviasi responden tidak hipertensi adalah sebesar 41,65 $\pm 8,32$ gram dan pada responden hipertensi adalah sebesar $51,52 \pm 6,74$ gram. Hasil uji statistik menunjukkan bahwa ada perbedaan tingkat konsumsi lemak antara responden tidak hipertensi dan hipertensi $\mathrm{p}=0,004$. Hal ini sesuai dengan penelitian di London ${ }^{19}$, yang menunjukkan asupan tinggi lemak berbanding lurus dengan kejadian obesitas dimana obesitas dapat menyebabkan hipertensi. ${ }^{20}$ Hasil penelitian ini juga sejaqlan dengan hasil penelitian di Teheran pada wanita dewasa yang menemukan ada hubungan antara asupan tinggi lemak dengan kejadian hipertensi. ${ }^{21}$ Subjek pada penelitian tersebut sering mengkonsumsi makanan western memiliki resiko tinggi terhadap peningkatan komponen sindroma metabolisme, antara lain resistensi insulin, peningkatan LDL, dan tekanan darah.

\section{SIMPULAN}

Kadar superoxide pada pasien tidak hipertensi lebih rendah tetapi kadar Nitric Oxide (NO) pada pasien tidak hipertensi lebih tinggi sedangkan tingkat asupan lemak pada pasien tidak hipertensi lebih rendah dibandingkan pasien hipertensi.Ada perbedaan Kadar Superoxide, Nitric Oxide (NO) dan tingkat asupan lemak pada pasien tidak hipertensi dan hipertensi .

\section{DAFTAR PUSTAKA}

1. Survei Nasional (Surkesnas) 2004 : SKRT 2004 vol 2 : Status Kesehatan Masyarakat Indonesia. Jakarta: Badan Penelitian dan Pengembangan Kesehatan; 2005. 
2. Yogiantoro M.Hypertensi Esensial Dalam Buku Ajar Ilmu Penyakit Dalam Jilid I Edisi IV. Jakarta: Fakultas Kedokteran Universitas Indonesia; 2006.

3. Sorof J, Daniels S. Obesity Hypertension in Children; A Problem of Epidemic Proportions. Hypertension. 2007; 40:441-447.

4. Santosa S,Ellya R. Peran F2-Isoprostan dan Nitrik Oksida Sebagai Penanada Stress Oksidatif dan Disfungsi Endotel pada Penderita Preeklamsi. Jurnal Kesehatan Masyarakat. 2007; 7 (1): 47-54.

5. Taniyama, Yoshihiro, Griendling KK. "Reactive oxygen species in the vasculature molecular and cellular mechanisms." Hypertension. 2003; 42 (6): 1075-1081.

6. Hermann M, Flammer A, Thomas F. Lüscher. "Nitric oxide in hypertension." The Journal of Clinical Hypertension. 2006; 8 (s12): 17-29.

7. Kaplan NM. Hypertension with pregnancy and pill, In Kaplan NM, editor, Clinical Hypertension.Williams \&Wilkins: Baltimore, USA; 1994.

8. Wang O, Lobstein. T. Worldwife trends in Childood Overweight on Obesity. International journal of Pediatric Obesity. 2006; 1:11-25.

9. Torrance B, McGuire A, Lewnczuk. Overweight, Physical activity and high blood pressure in children: a review of the literature. Vascular Health and Risk Management. 2007; 3(1): 139149.

10. Martins MA, Catta-Preta M, Mandarim-deLacerda CA, Aguila MB, Brunini TCM, et al. High fat diets modulate nitric oxide biosynthesis and antioxidant defence in red blood cells from C57BL/6 mice. Archives of biochemistry and biophysics. 2010; 499(1): 56-61.

11. Olofsson SO, Boren J. Apolipoprotein B: a clinically important apolipoprotein which assembles atherogenic lipoproteins and promotes the development of atherosclerosis. Journal of internal medicine. 2005; 258(5): 395-410.

12. Kuntoro H. Metode Sampling Dan Penentuan Besar Sampel. Pustaka Melati: Surabaya;2008.

13. Kestin AS, Ellis PA, Barnard MR. Effect of strenuous exercise on platelet activation state and reactivity. Circulation. 1993; 88(1): 15021511.

14. Sozmen B, Kozaz L, Taskiran D, Tuzens. Effect of $n$ dicycloprorylmethyl amino 2oxazoline (S 3341) on antioxidant status and nitric oxide in hypertensive patients. Current Medical Researh and Opinion. 1998; 14(2): 8996.

15. Nicholas K. Regulation of endothelial nitric oxide synthase by tetrahydrobiopterin in vascular disease. Arterioscler Thromb Vasc Biol. 2004; 24: 413-420.

16. Tyagi NS. Mechanisme of homocysteine induced oxidative stress, Am J Phhsiol Heart Circ Physiol. 2006; 289:2649-56.

17. Chao CL. Effect of methionine-induced hyperhomosistein on endothelium-dependent vasodilatation and oxidative status in healthy adults. Circulation. 2000; 101:485-90.

18. Tadddei S, Virdis A. Endothelial dysfunction in hypertension. J Nephr 2000; 13: 205-210.

19. Gregory JW, Lowe S. National Diet and Nutrition Survery: Young People Aged 4 to 18 Years : Report of the Diet and Nutrition Survey London, The Stationery Office; 2000.

20. Choi JW, Im MW, Pai SH. Nitric oxide production increases during normal pregnancy and decreases in preeclampsia. Annals of Clinical \& Laboratory Science. 2002; 32: 257-63.

21. Esmaillzadeh A, Mosug KFB, Willet W. Dietary 3 , pattern, insulin resistance and prevalence of the metabolic syndrome in women. Am J Clin Nutr. 2007; 85:910-8. 